\title{
TTR wt Allele
}

National Cancer Institute

\section{Source}

National Cancer Institute. TTR wt Allele. NCI Thesaurus. Code C79963.

Human TTR wild-type allele is located in the vicinity of $18 q 12.1$ and is approximately $7 \mathrm{~kb}$ in length. This allele, which encodes transthyretin protein, plays a role in the stabilization and transport of thyroxine and retinol. Mutations in the gene are associated with hyperthyroxinemia and amyloidosis types 1 and 7. 